\title{
Distribution and environmental correlations of picoeukaryotes in an Arctic fjord (Kongsfjorden, Svalbard) during the summer
}

\author{
Fang Zhang ${ }^{1}$, Shunan $\mathrm{Cao}^{1}$, Yuan Gao ${ }^{1,2}$ \& Jianfeng $\mathrm{He}^{1}$ \\ ${ }^{1}$ Key Laboratory for Polar Science, State Oceanic Administration, Polar Research Institute of China, Shanghai, China; \\ ${ }^{2}$ College of Ocean and Earth Sciences, Xiamen University, Xiamen, China
}

\begin{abstract}
Picoeukaryotes are numerous in the summer in the High-Arctic fjord Kongsfjorden, in western Spitsbergen, Svalbard. However, little research has been conducted on the community structure and diversity of picoeukaryotes. We conducted a detailed investigation of the distribution and environmental correlations of picoeukaryotes in Kongsfjorden in July 2012, using 454-pyrosequencing of 18S rDNA and redundant analysis. Eight classes were classified with proportions larger than $1 \%$. These were Mamiellophyceae, Chrysophyceae, Spirotrichea, Telonemea, Cryptophyceae, Bolidophyceae, Picomonadea and Dictyochophyceae. Five genera were classified, with Micromonas $(55.6 \%)$ and Bathycoccus $(7.8 \%)$ as the dominant genera. The diversity and composition of the picoeukaryote community were very distinct in different water masses sampled in the water column (i.e., vertically), but were not distinct from station to station (i.e., horizontally). Biodiversity was greater in the Atlantic waters than in glacial waters. Mamiellophyceae, Bolidophyceae, Picomonadea and Dictyochophyceae had significantly different distributions $(p<0.01)$ in the three water masses (surface water, intermediate water and transformed Atlantic Water). Nitrogen, salinity and temperature were the first three primary environmental factors shaping the community structure of picoeukaryotes.
\end{abstract}

\section{Keywords}

Chlorophytes; hydrography; water masses; nutrients

\section{Correspondence}

Fang Zhang, SOA Key Laboratory for Polar Science, Polar Research Institute of China, Shanghai 200136, China. E-mail: zhangfang@pric.org.cn

\section{Abbreviations}

ANOVA: analysis of variance; chl a: chlorophyll a; CTAB: cetyl trimethylammonium bromide; IW: intermediate water; NCBI: National Center for Biotechnology Information, Bethesda, MD, USA; OTU: operational taxonomic unit; PCR: polymerase chain reaction analysis; PVP: polyvinylpyrrodione; RDA: redundancy analysis; SW: surface water; TAW: transformed Atlantic Water

To access the supplementary material, please visit the article landing page

\section{Introduction}

Picoeukaryotes are vital to polar marine ecosystems, as they dominate the photosynthetic biomass throughout much of the year (Sherr et al. 2003; Lovejoy et al. 2007) and feature both abundant and diverse heterotrophic populations (Lovejoy et al. 2006). The heterotrophic fractions are also very important for carbon flows and nutrient remineralization (Sherr \& Sherr 2000). The mesoscale distribution of these free-living cells is correlated with global ocean circulation, as their movements are primarily determined by passive lateral advection and vertical mixing in the water column (Hamilton et al. 2008; Zhang et al. 2016). Both water mass type and the physicochemical factors within water masses influence picoeukaryote community distribution and diversity (Hamilton 2008; Zhang et al. 2016). The Arctic is warming much faster than are other regions (Steele et al. 2008; Serreze et al. 2009; Polyakov et al. 2010; Wiencke \& Hop 2016), with accompanying changes in temperature, salinity and nutrient levels in seawater are also being altered, and rapid transformations in global circulation in response to climate change are likely. Hence, it is imperative to gain a better understanding of picoeukaryote community composition and diversity, as well as the extent to which physicochemical factors influence the microbial community and how these interactions will be affected by projected oceanographic changes (Hamilton 2008; Doney et al. 2012).

Kongsfjorden $\left(79^{\circ} \mathrm{N}, 12^{\circ} \mathrm{E}\right)$ is an Arctic fjord located in northwestern Svalbard. An active tidal glacier at the head of the fjord causes marked gradients in both the water temperature and the salinity. Warm, saline Atlantic Water and colder, fresher Arctic Water commingle in the fjord 
(Wang et al. 2009), making this complex environment an ideal site for research on the impacts of climate change on the Arctic (Wesławski et al. 1988). Many studies have been carried out on the eukaryotic distribution in summer (Keck et al. 1999; Wiktor \& Wojciechowska 2005; Piwosz et al. 2009; Iversen \& Seuthe 2011; Seuthe et al. 2011 ; Kubiszyn et al. 2014; Piwosz \& Wiktor 2014; Piwosz et al. 2015). Conducted mainly on microplankton and nanoplankton and found that diatoms, these studies have found that the protistan community may be dominated by chrysophytes, dinoflagellates, chlorophytes, cryptophytes, pico-prasinophytes or ciliates. Although picoeukaryotes are numerous in Kongsfjorden during summer (Iversen \& Seuthe 2011), little research has focused on the regional distribution of picoeukaryotes in the upper water column. In the present study, we determined the distribution and environmental correlations of picoeukaryotes in relation to water mass distribution in Kongsfjorden. We also tested which environmental factors best explain the picoeukaryote assemblage structure.

\section{Material and methods}

\section{Sampling and environmental factor measurement}

Samples were collected from five stations in Kongsfjorden, western Spitsbergen, Svalbard (Fig. 1), during the period 11-16 July 2012. A Niskin bottle was used to collect $10 \mathrm{~L}$ of seawater from $0,5,10,20,30,50,75,100$, 150 and $200 \mathrm{~m}$ depths at stations $\mathrm{K} 1-\mathrm{K} 3$, from the first seven depths at station $\mathrm{K} 4$ and from the first five depths at station $\mathrm{K} 5$. Water temperatures and salinities were recorded directly using a Sea-Bird Scientific SBE 91 lplus conductivity-temperature-depth instrument. Nutrients, including phosphate $\left(\mathrm{PO}_{4}{ }^{3-}\right)$, nitrate+nitrite $\left(\mathrm{NO}_{3}+\mathrm{NO}_{2}\right)$, silicate ( $\mathrm{Si})$ and ammonia $\left(\mathrm{NH}_{4}^{+}\right)$, were collected at each depth. They were frozen at temperature of $-20^{\circ} \mathrm{C}$ and were measured in the Key Laboratory of Marine Ecosystem and Biogeochemistry, State Oceanic Administration, China, by a Skalar San++ nutrient automatic analyser (Zhang et al. 2016). Then, $500 \mathrm{ml}$ water samples were collected from each depth and filtered through $47 \mathrm{~mm}$

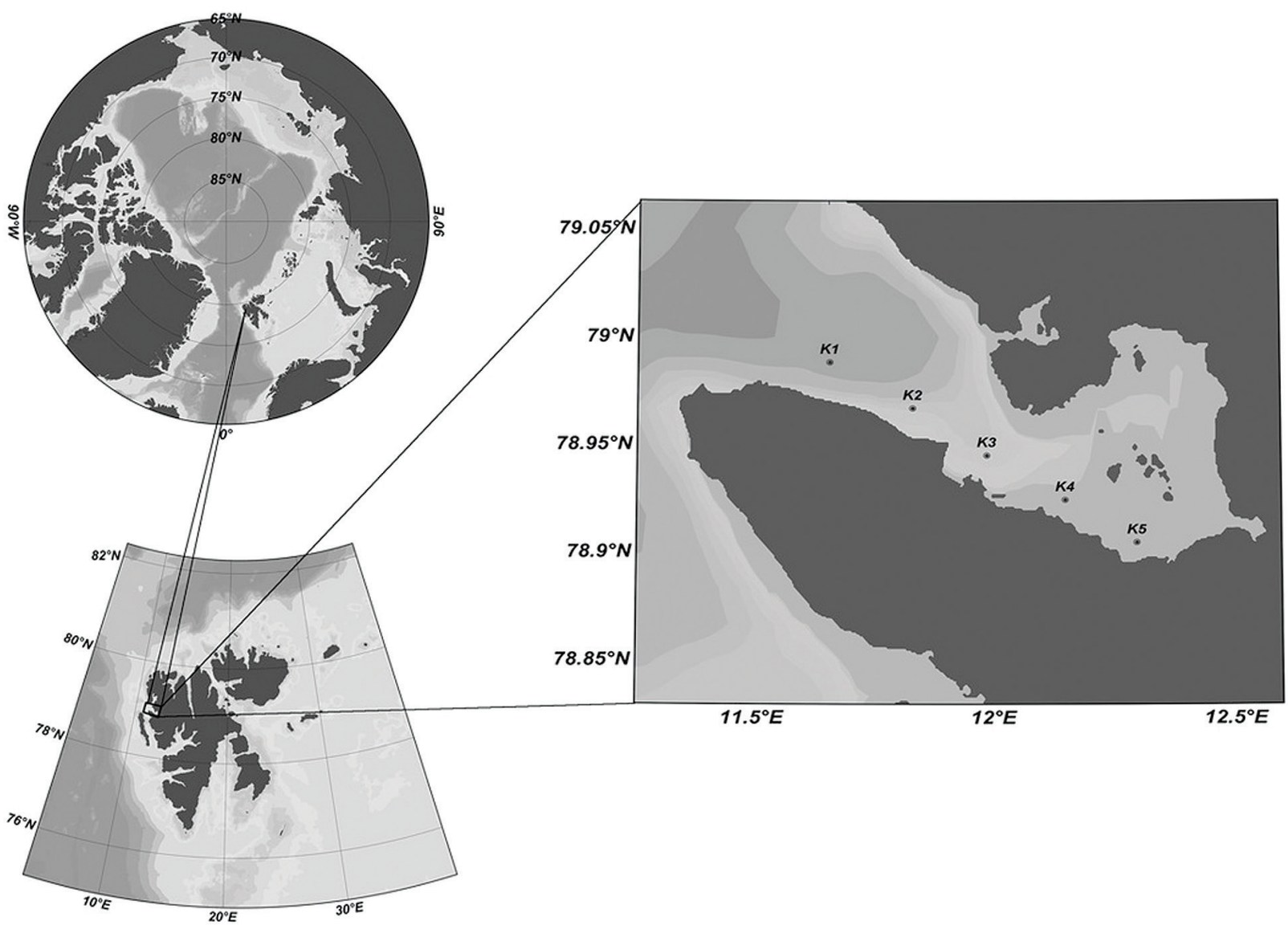

Fig. 1 Sampling sites in Kongsfjorden, Spitsbergen, Svalbard 
diameter GF/F glass filters. The filters were also frozen at a temperature of $-20^{\circ} \mathrm{C}$, and each filter was placed into a clean glass tube in the domestic laboratory. Chl $a$ was extracted with $10 \mathrm{ml} 90 \%$ acetone for $24 \mathrm{hr}$ in a $-20^{\circ} \mathrm{C}$ freezer and was measured with a Turner Designs 10 fluorometer (Parsons et al. 1984).

\section{Biodiversity and community composition of picoeukaryotes by 454-pyrosequencing}

Two-litre sub-samples were collected from depths of 0 , 30 (20) and $50 \mathrm{~m}$, which were chosen to sample different water masses, at stations $\mathrm{Kl}-\mathrm{K} 4$ and from depths of 0 and $20 \mathrm{~m}$ at station $\mathrm{K} 5$. The samples were pre-filtered using a $20-\mu \mathrm{m}$ mesh under gravity filtration. The filtrate was further filtered through a 47-mm diameter, 3- $\mu \mathrm{m}$-pore size polycarbonate filter (Nuclepore, Whatman) by using a $50-\mathrm{mmHg}$ vacuum, thus obtaining the $3-\mu \mathrm{m}$ fraction. The filtrate $(3 \mu \mathrm{m})$ was finally filtered onto a 0.2 - $\mu \mathrm{m}$-pore size polycarbonate filter (Nuclepore, Whatman) to collect the pico-fraction.

The process for analysing the biodiversity and community composition of picoeukaryotes, including DNA extraction, PCR amplification of rRNA genes, and the pyrosequencing and bioinformatics analyses, was as follows.

DNA extraction. The 0.2 - $\mu \mathrm{m}$ filters were put in the CTAB solution with a final concentration of $2 \%(1.4 \mathrm{M} \mathrm{NaCl}$, $100 \mathrm{mM}$ Tris- $\mathrm{HCl}, 4 \% \mathrm{PVP}, 70 \mathrm{mM} \beta$-mercaptoethanol, $\mathrm{pH} 8.0)$ to remove the cell wall, denature the protein and extract the DNA of the picoplankton. The CTAB solution was treated using lysozyme (final concentration, $5 \mathrm{mg} \mathrm{ml}^{-1}$ ) and proteinase $\mathrm{K}$ (final concentration, $10 \mathrm{mg} \mathrm{ml}^{-1}$ ). The lysates were extracted with phenolchloroform-isoamyl alcohol (25:24:1), and RNase was added (final concentration, $20 \mu \mathrm{g} \mathrm{ml}^{-1}$ ) to remove the RNA contamination. The phenol-chloroform-isoamyl alcohol extraction step was repeated. The aqueous phase (top) was precipitated with $2 / 3$ volume cold isopropanol at $-20^{\circ} \mathrm{C}$ overnight and was centrifuged at $12000 \mathrm{rpm}$ for $10 \mathrm{~min}$. The white/translucent pellets were washed with $70 \%$ ethanol, dried and then resuspended in $40 \mu \mathrm{l}$ TE buffer ( $\mathrm{pH} 8.0$ ). The DNA concentration and purity were checked by running the samples on $0.7 \%$ agarose gels.

PCR amplification of rRNA genes, pyrosequencing and bioinformatics analysis. The V4 region of the eukaryote SSU rRNA gene was amplified using the universal forward primer 3NDf (5'-GGCAAGTCTGGTGCCAG-3') and the reverse primers V4_euk_R2 (5'-ACGGTATCTRATCRTCTTCG-3') (Bråte, Logares et al. 2010). The fused forward primer 3NDf includes a 10-nucleotide barcode inserted between the Life Sciences primer A and the 3NDf primer. The barcodes were used to sort multiple samples in a single 454 GS-FLX run.

The PCRs were carried out in $20 \mu \mathrm{l}$ reaction volumes with a 20 -ng DNA template, $250 \mu \mathrm{M}$ dNTPs, $0.25 \mu \mathrm{M}$ of each primer, IX PCR buffer and 2.5 U Pfu Polymerase (Fermentas). The PCR condition involved initial denaturation at $95^{\circ} \mathrm{C}$ for $2 \mathrm{~min}$, followed by 25 cycles of denaturation at $94^{\circ} \mathrm{C}$ for $30 \mathrm{~s}$, annealing at $55^{\circ} \mathrm{C}$ for $30 \mathrm{~s}$ and extension at $72^{\circ} \mathrm{C}$ for $30 \mathrm{~s}$, with a final extension of $72^{\circ} \mathrm{C}$ for $10 \mathrm{~min}$. PCR products $(3 \mu \mathrm{l})$ were checked on a $2 \%$ agarose gel, purified using DNA gel extraction kit (Axygen, China), and quantified using the TBS-380 Mini-Fluorometer (Turner BioSystems). Following quantitation, the products from different samples were mixed at equal ratios for pyrosequencing with a Roche GS FLX platform. All of the process above was completed by the TinyGen Bio-Tech Company in Shanghai.

Chimeras were removed using the chimera.uchime programme in Mothur (version 1.32.0) (Schloss et al. 2009). Finally, sequences with high qualities ( $\geq 200 \mathrm{bp}$ length, quality score $\geq 25$, matched to barcode and primer, and containing no ambiguous characters) were aligned with the reference sequences in the Silva database (silva. seed_v115) (Pruesse et al. 2007) and were clustered to OTUs at $97 \%$ similarity with a cut-off of 80 compared with the reference sequences. The community diversity and similarity among all water samples were also analysed with OTUs of $97 \%$ similarity in Perl and Mothur (version 1.32.0) (Schloss et al. 2009). Then, the attributions of each sequence at different levels (from phylum to genus) were added according to the NCBI database. All singletons and sequences belonging to Metazoa and other traditional non-picoeukaryotes, including most diatoms, dinoflagellate, ciliates and cercozoa, and some chrysophytes, were removed, and R (version 3.1.2) was used to construct an alpha-diversity index (Shannon and invsimpson) and Good's coverage from the left sequences. Variations in the alpha-diversity between groups of samples were estimated by one-way ANOVA. We blasted the sequences that were not classified based on both Silva and NCBI databases. The sequence data were submitted to the National Center for Biotechnology Information Sequence Read Archives under BioProject ID PRJNA313965.

\section{Statistical analysis: picoeukaryotes and environmental factors}

Three statistical approaches were used to analyse the relationship between eukaryotic communities and environmental factors. The relationships between the biological group, including both the main classes and all 
the present OTUs, and their corresponding environmental group (environmental factors, including temperature, salinity, nutrients and chl a) were analysed using RDA (Canoco for Windows 4.5 software). Detrended correspondence analysis was used for the selection of RDA of both relationships, as the largest axial lengths were 2.61 (<3) (Leps \& Smilauer 2003).

\section{Results}

\section{Distribution of water masses and their hydrology}

The water temperature in Kongsfjorden in the summer of 2012 ranged from $2.14^{\circ} \mathrm{C}$ to $6.84^{\circ} \mathrm{C}$ (Fig. 2a), generally decreasing from the outer to the inner fjord. The highest temperatures $\left(5.04^{\circ} \mathrm{C}-6.84^{\circ} \mathrm{C}\right)$ were always at the surface
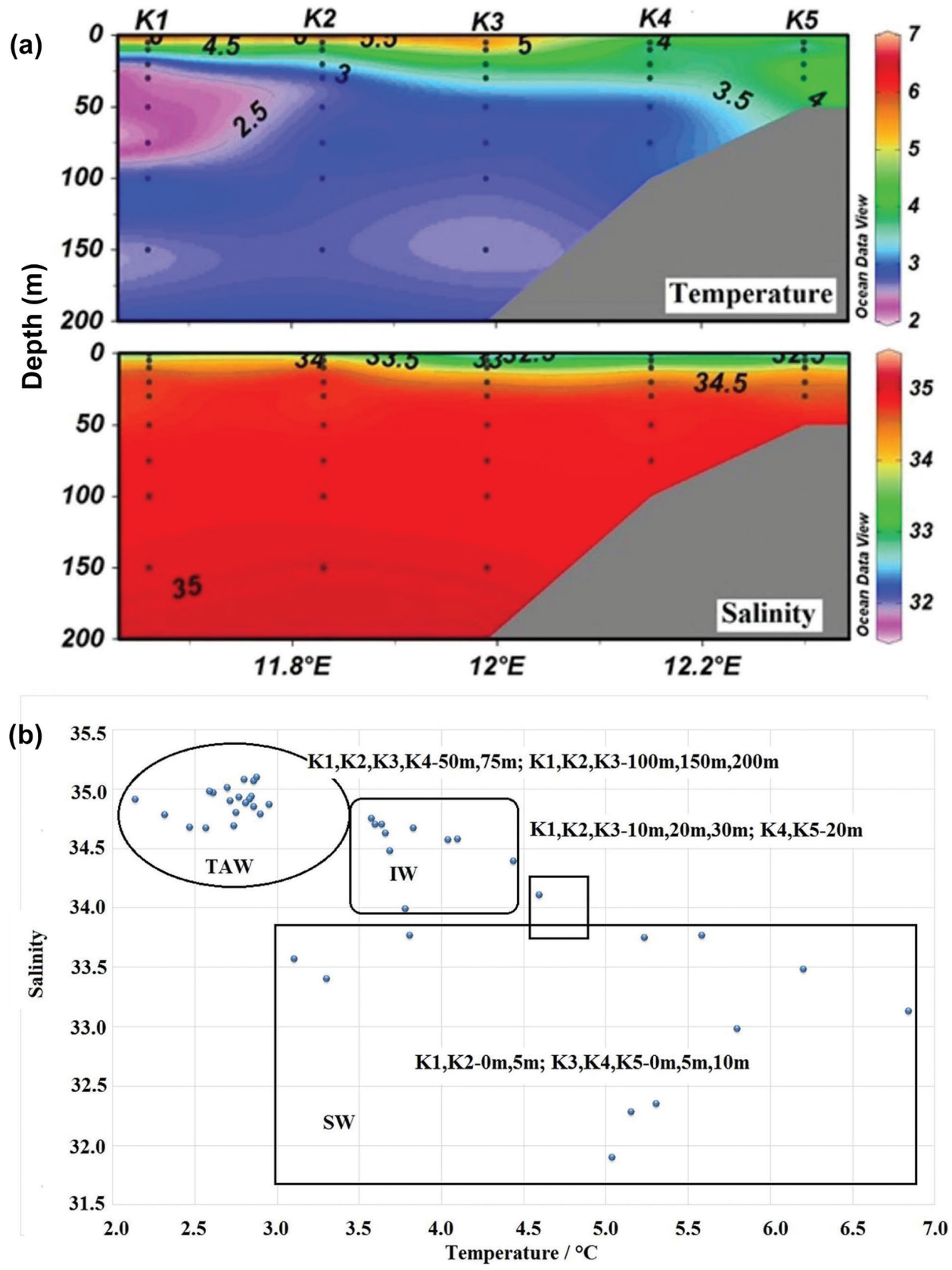

Fig. 2 The distribution of (a) temperatures $\left({ }^{\circ} \mathrm{C}\right)$ and salinity, and (b) water masses at the five stations in the Kongsfjorden. 
in vertical distributions, with low values at depths of $150 \mathrm{~m}$ at the three outer stations ( $\mathrm{K} 1, \mathrm{~K} 2$ and $\mathrm{K} 3$ ) and $5 \mathrm{~m}$ at the two inner stations ( $\mathrm{K} 4$ and $\mathrm{K} 5$ ). The salinity profiles showed water stratification, with values ranging from 31.90 to 35.10 (Fig. 2a). The salinity gradually decreased from the outer to the inner fjord at depths shallower than $50 \mathrm{~m}$. Three types of water mass were classified based on temperature and salinity (Fig. 2b), namely, SW, IW and TAW, following the classification scheme of Svendsen et al. (2002) and Cottier et al. (2005). SW included water depths of $0-5 \mathrm{~m}$ at the two outer stations (K1 and K2) and $0-10 \mathrm{~m}$ at the three inner stations (K3, K4 and $\mathrm{K} 5$ ). TAW included water depths no shallower than $50 \mathrm{~m}$ at the four stations in relatively deep waters. IW consisted of the water depths between SW and TAW.

\section{Community diversity and the composition of picoeukaryotes by pyrosequencing}

A total of 80794 sequences (reads) and 7597 OTUs (at 97\% similarity) were identified. The sequence number of each sample ranged from 3708 to 9093 , of which 370 to 641 OTUs were recognized with $97 \%$ similarity. Good's coverage estimator of the OTUs in the samples ranged from $90.51 \%$ to $94.82 \%$ (Table 1 ). Generally, SW had the fewest OTUs (1265) and IW had the most OTUs (1648). The three water masses shared 711 OTUs in all. SW and IW shared 1040 OTUs, IW and TAW shared 1195 OTUs, and SW and TAW shared 830 OTUs (Fig. 3).
The identified picoeukaryotes mainly belonged to seven divisions and eight classes (Table 2). Eight orders, five families, five genera and two species were classified with a proportion larger than $1 \%$ in all the reads. Phytoplankton made the biggest contribution to the sequencing libraries of the picoeukaryotic community, accounting for $75.9 \%$ in the total reads. Chlorophyta was the most common division of phytoplankton, accounting for $65.1 \%$ of the total reads, with Mamiellophyceae as the major class. Micromonas and Bathycoccus were the predominant genera, with Micromonas pusilla as the predominant species, accounting for $3.1 \%-20.2 \%$ and an average of $10.1 \%$ of the total reads. Bolidomonas pacifica was the only identified species of Bolidophyceae. Geminigeraceae and Teleaulax were the main identified order and genus of Cryptophyceae.

These eukaryotes were distributed differently at different stations and water depths and in different water masses (Fig. 4). Mamiellophyceae comprised large contributions to all the samples, with proportions of $32.8 \%-92.8 \%$, decreasing with increasing water depths (Fig. 4a). The relative DNA contributions to all sequences of Cryptophyceae gradually decreased from the surface to $50 \mathrm{~m}$ at the two outer stations ( $\mathrm{K} 1$ and $\mathrm{K} 2$ ), but increased at the innermost station (K5), with a relative large contribution at the middle depths (30 and $20 \mathrm{~m}$ ) of the two middle stations (K3 and K4). Telonomea mainly increased along with depths at stations K3-K5, with relatively smaller contributions at stations K1-K2. They preferred deep sea water to surface and glacial water in

Table 1 Summary information for pyrosequencing data from the 14 samples.

\begin{tabular}{|c|c|c|c|c|c|}
\hline Station-depth & Reads & OTUs & Shannon & Invsimpson & Coverage (\%) \\
\hline $\mathrm{K} 1-0 \mathrm{~m}$ & 7481 & 451 & 3.54 & 7.94 & 93.26 \\
\hline $\mathrm{K} 1-30 \mathrm{~m}$ & 4895 & 574 & 4.23 & 11.43 & 91.94 \\
\hline $\mathrm{k} 1-50 \mathrm{~m}$ & 4866 & 585 & 4.61 & 22.75 & 92.21 \\
\hline $\mathrm{K} 2-0 \mathrm{~m}$ & 6550 & 500 & 3.94 & 10.56 & 92.72 \\
\hline $\mathrm{K} 2-30 \mathrm{~m}$ & 4752 & 609 & 4.79 & 24.48 & 91.86 \\
\hline $\mathrm{K} 3-0 \mathrm{~m}$ & 5277 & 470 & 3.66 & 7.55 & 92.96 \\
\hline $\mathrm{K} 3-30 \mathrm{~m}$ & 6363 & 641 & 4.58 & 15.62 & 90.51 \\
\hline $\mathrm{k} 3-50 \mathrm{~m}$ & 5364 & 627 & 4.83 & 28.35 & 91.50 \\
\hline K4-0 m & 4501 & 428 & 3.51 & 6.95 & 93.96 \\
\hline $\mathrm{K} 4-20 \mathrm{~m}$ & 7359 & 562 & 4.30 & 14.70 & 91.56 \\
\hline K4-50 m & 5197 & 636 & 4.84 & 27.75 & 90.61 \\
\hline $\mathrm{K} 5-20 \mathrm{~m}$ & 9093 & 517 & 3.81 & 8.04 & 92.48 \\
\hline$p_{s}^{a}$ & 0.75 & 0.86 & 0.42 & 0.25 & - \\
\hline$p_{w}{ }^{a}$ & 0.0097 & 0.0072 & 0.00019 & 0.0007 & - \\
\hline
\end{tabular}

${ }^{a} p_{s}$ and $p_{w}$ represent the difference among different stations and water masses, respectively; $p$-values were obtained by one-way ANOVA. 
Kongsfjorden. Contributions of Chrysophyceae, Spirotrichea, Bolidophyceae, Picomonadea and Dictyochophyceae all showed increasing trends along with increasing water depths.

Generally, Mamiellophyceae showed decreased contributions from SW to TAW ( $p=0.002$ ) (Fig. 4b). There were also significant differences among the three water masses of Bolidophyceae, Picomonadea and Dictyochophyceae, with $p$-values of $0.0275,0.0066$ and 0.0127 , respectively. The DNA contributions of all these three classes increased from SW to TAW. The differences in the DNA contributions of the four classes mentioned above were mainly between SW and TAW. There was no significant difference between any of the three water masses for Chrysophyceae, Spirotrichea, Telonemea and Cryptophyceae,

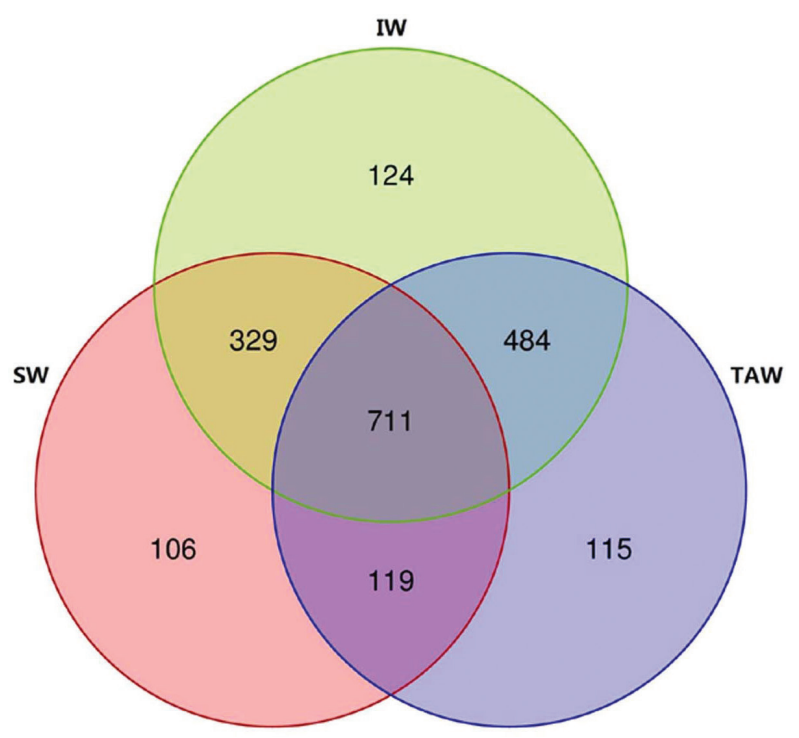

Fig. 3 Venn diagram for OTUs among different water masses. although Chrysophyceae and Spirotrichea also showed an increasing trend from SW to TAW.

According to the OTU diversity that was estimated by the Shannon index (Table 1), the diversity increased with the water depth, with the lowest values occurring at $0 \mathrm{~m}$ at station K5. However, the biodiversity estimate that was based on both Shannon and Simpson indexes were not significantly different $(p>0.05)$ among the different stations (horizontal distribution). There were no significant differences among the sequence numbers (reads) and the OTUs between all of the stations $(p>0.05)$ either. As to the eight classes with proportions $>1 \%$ (Fig. 4), only Spirotrichea $(p=0.029)$ and Telonemea $(p=0.0036)$ showed significant differences among the five stations. The picoeukaryote communities were strongly associated with water mass type, as revealed by the significant differences among the three water masses (SW, IW and TAW): the differences of the reads, OTUs and the alpha-diversity indexes (Shannon and Invsimpson) were all significant $(p<0.01$ or 0.001$)$ (Table 1$)$.

\section{Correlations with the environmental factors}

An RDA analysis revealed the relationship among water masses, environmental variables and the picoeukaryote species (OTUs) (Fig. 5): the canonical eigenvalues explain $66.96 \%$ of the total relationships, and the sum of the first two axes explains $57.13 \%$ of the total relationships. The contributions of environmental factors to the microbial distributions were, from highest to lowest, nitrogen $(15.72 \%, p=0.48)>$ salinity $(12.74 \%, p=$ $0.003)>$ temperature $(11.74 \%, p=0.132)>$ phosphate $(10.39 \%, p=0.075)>$ silicate $(9.74 \%, p=0.9)>\mathrm{chl}$ a $(9.61 \%, p=0.847)$. Their interactions had different correlations with the community structure at different sampling sites. Temperature and chl a were the primary environmental factors influencing the community

Table 2 Composition of picoeukaryotic community at different levels obtained by 454-pyrosequncing and bioinformatics.

\begin{tabular}{|c|c|c|}
\hline & Compositions with their proportions larger than $1 \%$ & $\begin{array}{l}\text { Unclassified } \\
\text { proportions (\%) }\end{array}$ \\
\hline Phylum & $\begin{array}{l}\text { Chlorophyta (65.1\%), Chrysophyta (6.3\%), Ciliophora (5.8\%), Ochrophyta (2.9\%), Telonemia (2.7\%), Cryptophyta (1.6\%), } \\
\text { Picozoa (1.4\%) }\end{array}$ & 12.9 \\
\hline Class & $\begin{array}{l}\text { Mamiellophyceae (64.2\%), Chrysophyceae (6.4\%), Spirotrichea (5.8\%), Telonemea (2.7\%), Cryptophyceae (1.6\%), } \\
\text { Bolidophyceae (1.5\%), Picomonadea (1.4\%), Dictyochophyceae (1.2\%) }\end{array}$ & 12.9 \\
\hline Order & $\begin{array}{l}\text { Mamiellales (63.4\%), Choreotrichia (3.2\%), Telonemida (2.7\%), Bolidomonadales (1.6\%), Cryptomonadales (1.4\%), } \\
\text { Picomonadida (1.4\%), Oligotrichia (1.3\%), Peridiniales (1.0\%) }\end{array}$ & 23.1 \\
\hline Family & Mamiellaceae (55.3\%), Bathycoccaceae (7.8\%), Bolidomonadaceae (1.5\%), Telonemidae (2.7\%), Geminigeraceae (1.1\%) & 29.3 \\
\hline Genus & Micromonas (55.6\%), Bathycoccus (7.8\%), Telonema (2.7\%), Bolidomonas (1.5\%), Teleaulax (1.1\%) & 29.4 \\
\hline Species & Micromonas pusilla (10.4\%), Bolidomonas pacifica (1.2\%) & 49.5 \\
\hline
\end{tabular}




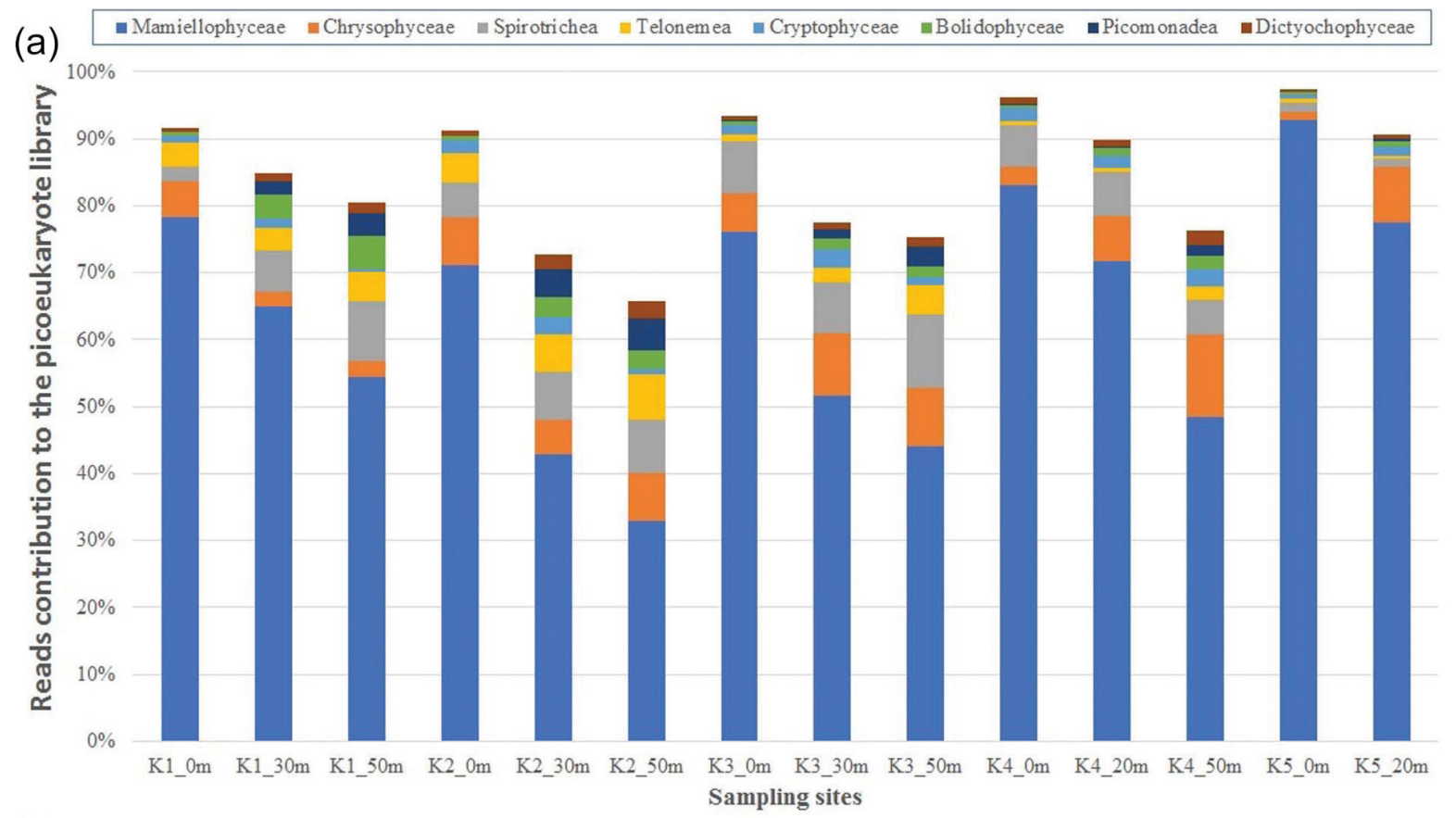

(b)

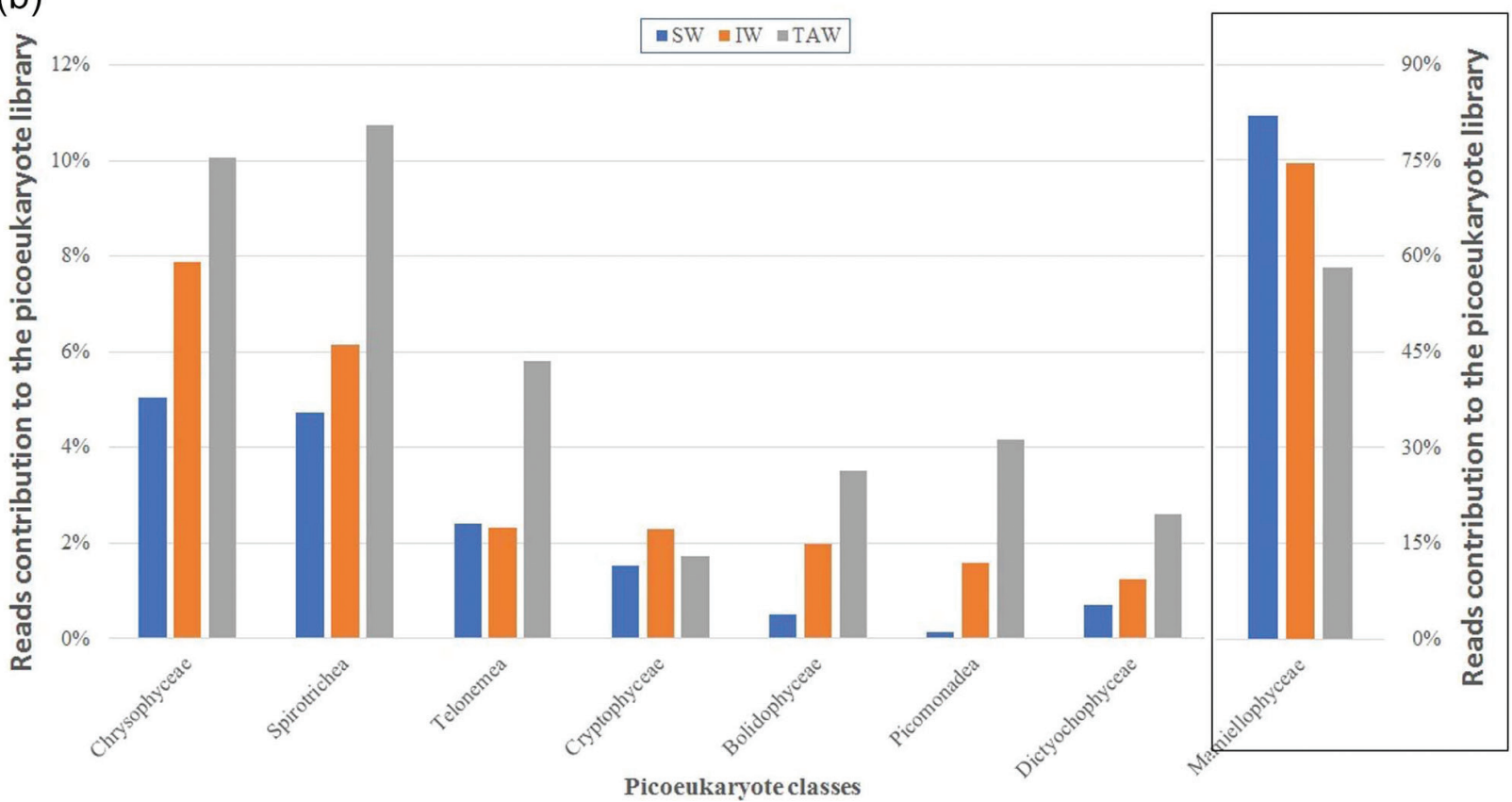

Fig. 4 Proportions of the 14 classes of picoeukaryotes with average proportions of no less than 1\% in Kongsfjorden: (a) at different stations and depths; (b) at different water masses.

structure in SW. Comparatively, nitrogen and phosphate had the main influence on the community structure in TAW. Salinity became more important than temperature on the community from surface to deep water, whereas nitrogen and phosphate became more important than salinity from IW to TAW. Community structures at the outermost station (K1) had the environmental correlations most different from the others: the community were influenced strongly by nutrients and slightly by temperature. 


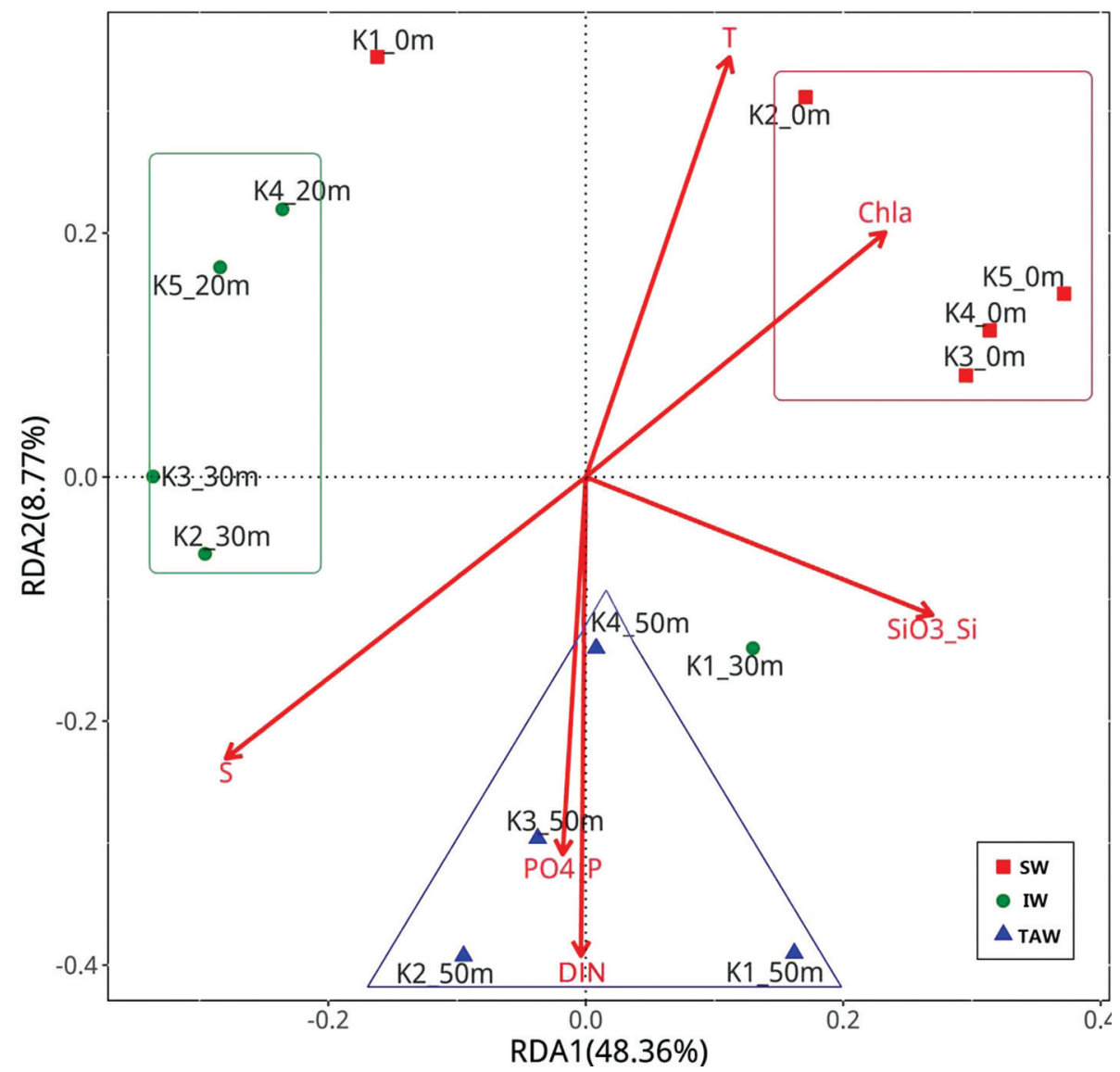

Fig. 5 Relationships of picoeukaryote community structure at different sampling sites with physiochemical factors in an ordination diagram with the first two axes of the RDA. Red arrows with different lengths denote relative correlations of different independent variables with the biological factors. $\mathrm{T}$, temperature; S, salinity; DIN, $\mathrm{NO}_{3}+\mathrm{NO}_{2}$; chla, chl a.

\section{Discussion}

Kongsfjorden is influenced by both Arctic and Atlantic water masses as well as glacial meltwater. The composition of water masses changes seasonally within the fjord. In addition to SW and TAW, local water with high salinity levels $(>34.4)$ and low temperatures $\left(<1.0^{\circ} \mathrm{C}\right)$, along with winter cooled water with similar salinity but lower temperatures $\left(<-0.5^{\circ} \mathrm{C}\right)$, may also exist in the fjord inlet (Svendsen et al. 2002). However, neither water masses were present in our study. They were replaced by IW and TAW in summer, as shown by the changes in temperature, with especially low values in the water column at each station (Fig. 2). The SW mass was thicker than that during the period 1996-2000 (Svendsen et al. 2002) and was thicker in the inner fjord than in the outer fjord. This may be in accordance with the conclusion that both sea ice and glacier melt increase dramatically as the Arctic continues to warm, which intensifies the influx of freshwater into the SW of Kongsfjorden (Hop et al. 2002). Moreover, deep-water temperatures are also changing because the West Spitsbergen Current is becoming warmer Piquet et al. 2014).

Chlorophyta may dominate in Kongsfjorden during the summer (Piwosz et al. 2015). Micromonas and Bathycoccus are both pan-Arctic (Lovejoy et al. 2007) and are abundant in marine coastal waters (Kilias et al. 2014). As the two main genera, their distribution trends were different, especially at the outer stations (Supplementary Fig. S1s). Micromonas preferred SW, whereas Bathycoccus preferred TAW. Chrysophyta are also abundant in Kongsfjorden during summer (Wiktor \& Wojciechowska 2005; Iversen \& Seuthe 2011; Kubiszyn et al. 2014). A type of uncultured marine picoeukaryote was found to be the main phylotype of chrysophytes, with average contributions to DNA of $2.3 \%$. Almost no Haptophyta were found in our study. This is an obvious difference compared with the findings of previous studies (Kubiszyn et al. 2014; 
Piwosz et al. 2015). This may be due to primer mismatch because the primers used in our study are universal and are not specified for Haptophyta. Cryptophyta (Cryptophyceae) were always abundant in Kongsfjorden (Piwosz et al. 2009; Kubiszyn et al. 2014). However, Cryptophyta may have low contributions (Piquet et al. 2014), and they only accounted for $1.6 \%$ in the picoeukaryotes. Bolidophyceae is closely related to diatoms genetically, but morphologically lacks a silica frustule (Guillou et al. 1999). This phylotype was also found previously in Kongsfjorden (Piwosz et al. 2015), and is one of the main components in the pico-library. Dictyochophyceae is common in Arctic seas (Terrado et al. 2013), and Pedinellales was also found in Kongsfjorden during the summer, by Piwosz et al. (2015). Ciliophora are the main heterotrophs during both summer and spring (Kubiszyn et al. 2014; Piquet et al. 2014). The pico-ciliates were also important in the pico-library, mainly belonging to Choreotrichia (3.2\%) and Oligotrichia (1.3\%). Although the Spirotrichea and Tintinnida were found in shallow waters $(0-30 \mathrm{~m})$ (Feng et al. 2014), the pico-fractions of Spirotrichea preferred deep water to shallow water. Picozoa are also important heterotrophic picoeukaryotes (Seenivasan et al. 2013). Telonemia is a new phylum that is affiliated with chromist lineages and is genetically closely related to cryptophytes and haptophytes (Shalchian-Tabrizi et al. 2006). Telonemia are also heterotrophic predators that feed on a wide range of bacteria and pico- to nano-sized phytoplankton and are distributed globally in marine waters (Bråte, Klaveness et al. 2010; Bråte, Logares et al. 2010).

Our biological sampling sites were situated in different water masses driven by different forces: the SW is mainly propelled by wind and freshwater, whereas the IW and TAW are strongly influenced by processes in the adjacent shelf area (Svendsen et al. 2002; Cottier et al. 2005). Both the water source and the transporting process influence the biodiversity and community structure of eukaryotes. The plankton likely vary because of their environmental sensitivity (Hop et al. 2006; Doney et al. 2012). Both primary and secondary production, as well as energy flowing through the food web, are likely to be altered by environmental changes (Polis \& Hurd 1996; Hamilton et al. 2008). In our study, the species numbers (OTUs) and biodiversity (Shannon and Simpson indexes) of the picoeukaryotic community were both sensitive to the variation of water masses in Kongsfjorden, but they are much less sensitive to environmental changes along the gradient from the inner to the outer fjord. The glacier water seemed harmful to the picoeukaryote community, and the innermost station had the least species and biodiversity. Comparatively, Atlantic Water brought many species into the fjord, so IW had the largest species numbers and TAW had the greatest biodiversity. Fewer species, for example, M. pusilla, were Arctic species and preferred fresh SW. Comparatively, more phylotypes, that is, Cryptophyceae, Spirotrichea, Bolidophyceae, Picomonadea, Telonemea and Dictyochophyceae, were likely brought by the influx of Atlantic Water, as they showed high relative DNA contributions to total reads at TAW.

In addition to water mass type, the physicochemistry of a water mass also determines the make-up of the biological community. Macronutrients exhibited stratification in the water column of Kongsfjorden during the summer of 2012 (H. Jin and Z. Ji, pers. comm.). Run-off from glacial melt and snowmelt contributes the bulk of the nutrient supply of the fjord during summer (Ji et al. 2014). The concentrations of nitrogen, phosphate and silicate were relatively high in the inner fjord, especially in the SW, shaping the community structure (Piquet et al. 2014). Nitrogen was the most important physicochemical factor controlling the community structure of picoeukaryotes. Deep waters with low temperatures and high concentrations of nutrients had correspondingly high community diversity. Micromonas in Kongsfjorden were strongly correlated with warm and oligotrophic seawater, as in the central Arctic Ocean (Zhang et al. 2015). Similar to conditions during the spring bloom (Piquet et al. 2014), the diversity of picoeukaryotes exhibited an inverse relationship with total autotrophic biomass (chl a) ( $p=0.001, R=-0.800)$.

\section{Conclusion}

Our study has shown that the picoeukaryote community in Kongsfjorden was determined by water mass type and the physicochemistry of the water mass. The diversity and distribution of picoeukaryotes were very distinct in different water masses (vertical direction), but were not distinct in the horizontal direction, that is, from innermost station to outermost station in the fjord. The fjord's changing physiochemical environment (Keck et al. 1999; Hop et al. 2006; Seuthe et al. 2011; Hegseth \& Tverberg 2013; Kubiszyn et al. 2014) will continue to impact its picoeukaryotes. Our study results suggest that Atlantic-originating phylotypes-Cryptophyceae, Spirotrichea, Bolidophyceae, Picomonadea, Telonemea and Dictyochophyceae-may thrive in the future as the influence of Atlantic Water increases in the fjord (Keck et al. 1999; Hop et al. 2006; Hegseth et al. 2013; Kubiszyn et al. 2014). Long-term monitoring of the biodiversity and community structure of picoeukaryotes is needed to study these changes. This will also provide important basic data to help us understand the changes in the entire marine ecosystem in Kongsfjorden. 


\section{Acknowledgements}

The data were issued by the Data-sharing Platform of Polar Science (http://www.chinare.org.cn) maintained by the Polar Research Institute of China and the Chinese National Arctic \& Antarctic Data Center. We thank Prof. Haiyan Jin, Dr Zhongqiang Ji and other colleagues in the Second Institute of Oceanography, State Oceanic Administration, for providing the nutrients and chl $a$ data.

\section{Disclosure statement}

The authors report no conflict of interest.

\section{Funding}

This work was supported by the National Natural Science Foundation of Shanghai (16ZR1439800), the Natural Science Foundation of China (41206189) and the Chinese Projects for Investigations and Assessments of the Arctic and Antarctic (CHINARE201 1-20).

\section{References}

Bråte J., Klaveness D., Rygh T., Jakobsen K.S. \& ShalchianTabrizi K. 2010. Telonemia-specific environmental 18S rDNA PCR reveals unknown diversity and multiple marinefreshwater colonizations. BMC Microbiology 10, 168-176, http://dx.doi.org/10.1186/1471-2180-10-168.

Bråte J., Logares R., Berney C., Ree D.K., Klaveness D., Jakobsen K.S. \& Shalchian-Tabrizi K. 2010. Freshwater Perkinsea and marine-freshwater colonizations revealed by pyrosequencing and phylogeny of environmental rDNA. ISME Journal 4, 1144-1153, http://dx.doi. org/10.1038/ismej.2010.39.

Cottier F., Tverberg V., Inall M.E., Svendsen H., Nilsen F. \& Griffiths C. 2005. Water mass modification in an Arctic fjord through cross-shelf exchange: the seasonal hydrography of Kongsfjorden, Svalbard. Journal of Geographical Research-Oceans 110, article no. C12005, http://dx.doi. org/10.1029/2004JC002757.

Doney S.C., Ruckelshaus M., Emmett Duffy J., Barry J.P., Chan F., English C.A., Galindo H.M., Grebmeier J.M., Hollowed A.B., Knowlton N., Polovina J., Rabalais N.N., Sydeman W.J. \& Talley L.D. 2012. Climate change impacts on marine ecosystems. Annual Review of Marine Science 4, 11-37, http:// dx.doi.org/10.1146/annurev-marine-041911-111611.

Feng M., Zhang W. \& Xiao T. 2014. Spatial and temporal distribution of tintinnid (Ciliophora: Tintinnida) communities in Kongsfjorden, Svalbard (Arctic), during summer. Polar Biology 37, 291-296, http://dx.doi.org/10.1007/ s00300-013-1442-1.

Guillou L., Chretiennot-Dinet M.J., Medlin L.K., Claustr H., Goer S.L. \& Vaulot D. 1999. Bolidomonas: a new genus with two species belonging to a new algal class: Bolidophyceae
(Heterokonta). Journal of Phycology 35, 368-381, http://dx. doi.org/10.1046/j.1529-8817.1999.3520368.x.

Hamilton A.K., Lovejoy C., Galand P.E. \& Ingram R.G. 2008. Water masses and biogeography of picoeukaryote assemblages in a cold hydrographically complex system. Limnology and Oceanography 53, 922-935, http://dx.doi. org/10.4319/lo.2008.53.3.0922.

Hegseth E.N. \& Tverberg V. 2013. Effect of Atlantic Water inflow on timing of the phytoplankton spring bloom in a High Arctic fjord (Kongsfjorden, Svalbard). Journal of Marine Systems 113-114, 94-105, http://dx.doi.org/ 10.1016/j.jmarsys.2013.01.003.

Hop H., Falk-Petersen S., Svendsen H., Kwasniewski S., Pavlov V., Pavlova O. \& Søreide J.E. 2006. Physical and biological characteristics of the pelagic system across Fram Strait to Kongsfjorden. Progress in Oceanography 71, 182-231, http:// dx.doi.org/10.1016/j.pocean.2006.09.007.

Hop H., Pearson T., Hegseth E.N., Kovacs K.M., Wiencke C., Kwasniewski S., Eiane K., Mehlum F., Gulliksen B., Wlodarska-Kowalczuk M., Lydersen C., Weslawski J.M., Cochrane S., Gabrielsen G.W., Leakey R.J.G., Lønne O.J., Zajaczkowski M., Falk-Petersen S., Kendall M., Wängberg S.-Å., Bischof K., Voronkov A.Y., Kovaltchouk N.A., Wiktor J., Poltermann M., di Prisco G., Papucci C. \& Gerland S. 2002. The marine ecosystem of Kongsfjorden, Svalbard. Polar Research 21, 167-208, http://dx.doi.org/10.3402/ polar.v2lil.6480.

Iversen R.K. \& Seuthe L. 2011. Seasonal microbial processes in a high-latitude fjord (Kongsfjorden, Svalbard): I. Heterotrophic bacteria, picoplankton and nanoflagellates, Polar Biology 34, 731-749, http://dx.doi.org/10.1007/ s00300-010-0929-2.

Ji Z., Gao S., Jin H., He J., Bai Y., Wang B., Yang Z. \& Chen J. 2014. Nutrients distribution and the influence factors of seawater in Arctic Kongsfjorden, summer 2010. Acta Oceanologica Sinica 36, 80-89. (In Chinese.)

Keck A., Wiktor J., Hapter R. \& Nilsen R. 1999. Phytoplankton assemblages related to physical gradients in an Arctic, glacier-fed fjord in summer. ICES Journal of Marine Science 56, 203-214, http://dx.doi.org/10.1006/ jmsc. 1999.0631.

Kilias E.S., Nöthing E.M., Wolf C. \& Metfies K. 2014. Picoeukaryote plankton composition off west Spitsbergen at the entrance to the Arctic Ocean. Journals of Eukaryotic Microbiology 61, 569-579, http://dx.doi.org/10.1111/jeu.12134.

Kubiszyn A.M., Piwosz K. \& Wiktor J.M. 2014. The effect of inter-annual Atlantic Water inflow variability on the planktonic protist community structure in the west Spitsbergen waters during the summer. Journal of Plankton Research 36, 1190-1203, http://dx.doi.org/10.1093/ plankt/fbu044.

Leps J. \& Smilauer P. 2003. Multivariate analysis of ecological data using CANOCO. Cambridge: Cambridge University Press.

Lovejoy C., Massana R. \& Pedros-Alio C. 2006. Diversity and distribution of marine microbial eukaryotes in the Arctic Ocean and adjacent seas. Applied Environmental Microbiology 72, 3085-3095, http://dx.doi.org/10.1128/ AEM.72.5.3085-3095.2006. 
Lovejoy C., Vincent W.F., Bonilla S., Roy M.-J., Martineau R., Terrado M., Potvin R., Massana M.-J. \& Pedros-Alio C. 2007. Distribution, phylogeny, and growth of cold-adapted picoprasinophytes in Arctic seas. Journal of Phycology 43, 7889, http://dx.doi.org/10.1111/j.1529-8817.2006.00310.x.

Parsons T.R., Maita Y. \& Lalli C.M. 1984. A manual of chemical and biological methods for seawater analysis. Oxford: Pergamon Press.

Piquet A.T., Van de Poll W.H., Visser R.J.W., Wiencke C., Bolhuis H. \& Buma A.G.J. 2014. Springtime phytoplankton dynamics in Arctic Krossfjorden and Kongsfjorden (Spitsbergen) as a function of glacier proximity. Biogeosciences 11, 2263-2279, http://dx.doi.org/10.5194/ bg-11-2263-2014.

Piwosz K., Spich K., Całkiewicz J., Weydmann A., Kubiszyn A.M. \& Wiktor J.M. 2015. Distribution of small phytoflagellates along an Arctic fjord transect. Environmental Microbiology 17, 2393-2406, http://dx.doi.org/ 10.1111/1462-2920.12705.

Piwosz K., Walkusz W., Hapter R., Wieczorek P., Hop H. \& Wiktor J. 2009. Comparison of productivity and phytoplankton in a warm (Kongsfjorden) and a cold (Hornsund) Spitsbergen fjord in mid-summer 2002. Polar Biology 32, 549-559, http://dx.doi.org/10.1007/s00300-008-0549-2.

Polis G.A. \& Hurd S.D. 1996. Linking marine and terrestrial food webs: allochthonous input from the ocean supports high secondary productivity on small islands and coastal land communities. American Naturalist 147, 396-423, http://dx.doi.org/10.1086/285858.

Polyakov I.V., Timokhov L.A., Alexeev V.A., Baconc S., Dmitrenko I.A., Fortiere L., Frolovb I.E., Gascard J.-C., Hanseng E., Ivanovah V.V., Laxon S., Mauritzen C., Perovich D., Shimada K., Simmons H.L., Sokolov V.T., Steelem M. \& Toole J. 2010. Arctic Ocean warming contributes to reduced polar ice cap. Journal of Physical Oceanography 40, 2743-2756, http://dx.doi.org/10.1175/2010JPO4339.1.

Pruesse E., Quast C., Knittel K., Fuchs B.M., Ludwig W., Peplies J. \& Glöckner F.O. 2007. SILVA: a comprehensive online resource for quality checked and aligned ribosomal RNA sequence data compatible with ARB. Nucleic Acids Research 35, 7188-7196, http://dx.doi.org/10.1093/nar/gkm864.

Schloss P.D., Westcott S.L., Ryabin T., Hall J.R., Hartmann M., Hollister E.B., Lesniewski R.A., Oakley B.B., Parks D.H., Robinson C.J., Sahl J.W., Stres B., Thallinger G.G., Van Horn D.J. \& Weber C.F. 2009. Introducing mothur: OpenSource, Platform-Independent, Community-Supported Software for Describing and Comparing Microbial Communities. Applied and Environmental Microbiology 75, 7537-7541, http://dx.doi.org/10.1128/AEM.01541-09.

Seenivasan R., Sausen N., Medlin L.K. \& Melkonian M. 2013. Picomonas judraskeda gen. et sp. nov.: the first identified member of the Picozoa phylum nov., a widespread group of picoeukaryotes, formerly known as 'Picobiliphytes'. PLoS One 8, e59565, http://dx.doi.org/10.1371/journal. pone.0059565.

Serreze M.C., Barrett A.P., Stroeve J.C., Kindig D.N. \& Holland M.M. 2009. The emergence of surface-based Arctic amplification. Cryosphere 3, 11-19, http://dx.doi. org/10.5194/tc-3-11-2009.
Seuthe L., Iversen K.R. \& Narcy F. 2011. Microbial processes in a high-latitude fjord (Kongsfjorden, Svalbard): II. Ciliates and dinoflagellates. Polar Biology 34, 751-766, http://dx. doi.org/10.1007/s00300-010-0930-9.

Shalchian-Tabrizi K., Eikrem W., Klaveness D., Vaulot D., Mine M.A., LeGall F., Romari K., Throndsen J., Botnen A., Massana R., Thomsen H.A. \& Jakobsen K.S. 2006. Telonemia, a new protist phylum with affinity to chromist lineages. Proceedings of the Royal Society B: Biological Sciences 273, 1833-1842, http://dx.doi.org/10.1098/ rspb.2006.3515.

Sherr B.F. \& Sherr E.B. 2000. Marine microbes: an overview. In D.L. Kirchman (ed.): Microbial ecology of the oceans. Pp. 13-46. New York: Wiley-Liss.

Sherr E.B., Sherr B.F., Wheeler P.A. \& Thompson K. 2003. Temporal and spatial variation in stocks of autotrophic and heterotrophic microbes in the upper water column of the central Arctic Ocean. Deep-Sea Research I: Oceanographic Research Papers 50, 557-571, http://dx.doi.org/10.1016/ S0967-0637(03)00031-1.

Steele M., Ermold W. \& Zhang J. 2008. Arctic Ocean surface warming trends over the past 100 years. Geophysical Research Letters 35, L02614, http://dx.doi. org/10.1029/2007GL031651.

Svendsen H., Beszczynska-Møller A., Hagen J.O., Lefauconnier B., Tverberg V., Gerland S., Ørbæk J.B., Bischof K., Papucci C., Zajaczkowski M., Azzolini R., Bruland O., Wiencke C., Winther J.-G. \& Dallmann W. 2002. The physical environment of Kongsfjorden-Krossfjorden, an Arctic fjord system in Svalbard. Polar Research 21, 133-166, http://dx.doi. org/10.1111/j.1751-8369.2002.tb00072.x.

Terrado R., Scarcella K., Thaler M., Vincent W.F. \& Lovejoy C. 2013. Small phytoplankton in Arctic seas: vulnerability to climate change. Biodiversity 14, 2-18.

Wang G., Guo C., Luo W., Cai M. \& He J. 2009. The distribution of picoplankton and nanoplankton in Kongsfjorden, Svalbard during late summer 2006. Polar Biology 32, 1233-1238, http://dx.doi.org/10.1080/14888386.201 2.704839 .

Wesławski J.M., Zajaczkowski M., Kwaśniewski S., Jezierski J. \& Moskal W. 1988. Seasonality in an Arctic fjord ecosystem: Hornsund, Spitsbergen. Polar Research 6, 185-189, http://dx.doi.org/10.3402/polar.v6i2.6861.

Wiencke C. \& Hop H. 2016. Ecosystem Kongsfjorden: new views after more than a decade of research. Polar Biology 39, 1679-1687, http://dx.doi.org/10.1007/ s00300-016-2032-9.

Wiktor J. \& Wojciechowska K. 2005. Differences in taxonomic composition of summer phytoplankton in two fjords of west Spitsbergen, Svalbard. Polish Polar Research 26, 259-268.

Zhang F., He J., Lin L. \& Jin H. 2015. Dominance of picophytoplankton in the newly open surface water of the central Arctic Ocean. Polar Biology 38, 1081-1089, http://dx.doi. org/10.1007/s00300-015-1662-7.

Zhang F., Lin L., Gao Y., Cao S. \& He J. 2016. Ecophysiology of picophytoplankton in different water masses of the northern Bering Sea. Polar Biology 39, 1381-1397, http:// dx.doi.org/10.1007/s00300-015-1860-3. 